\title{
A Comparative Study on the Coordinated Development of Service Trade and Ecological Environment between China, Japan and the South Korea
}

\author{
Hong Li, Yao Xie* \\ School of Management, Tianjin University of Technology, Tianjin 300384, China. \\ *971006150@qq.com
}

Keywords: Trade in services; ecological environment; coordination degree; entropy weight method.

\begin{abstract}
This article selects the region of China, Japan and South Korea as the object of research. Based on the theory of national competitive advantage, the evaluation index system of the coupling coordination degree of service trade and environment is constructed. In addition, relevant data in 2007-2016 were selected as samples, than we through the entropy weight method to evaluate the weight of each index objectively. On this basis of which, the coordination degree model of the coupling system constructed in this paper is used to evaluate the coordination degree, which showed that Japan had the highest degree of coordination, fluctuating within [0.607, 0.759].The annual average coordination degree of South Korea is 0.599 , whose fluctuation range of coordination degree is large, from reluctant coordination gradually to intermediate coordination, from the intermediate level down to near disorder. But China has the lowest degree of coordination, fluctuating within [0.257,0.595].Based on the above assessment results, we puts forward some suggestions such as optimizing the mode of production and service trade, accelerating the optimization and upgrading of service trade structure, improving the quality of labor force in service industry.
\end{abstract}

\section{Introduction}

With the development of economic globalization and international trade liberalization, the development of service industry in the global economy accounted for more than $60 \%$ above, trade in services in world trade accounted for a quarter, more than half of the total global FDI flows to the services. Trade in services is increasingly affecting the economic and environmental development of countries. China, Japan and the South Korea are both East Asia and the region with active world economic development, which has exerted a significant impact on the development of world service trade. Therefore, further study of service trade and the ecological environment of the two coupling interaction, and analyzes the service trade and the influence factors of the ecological environment coordinated development will help to adjust the foreign trade policy and environmental protection measures, optimization of trade in services and provides the basis for the ecological environment, which also has important theoretical and realistic significance.

\section{Literature References}

Domestic and foreign scholars mainly focus on two aspects of service trade. First, research on the influencing factors of international competitiveness of service trade. Paolo and Valentina (2005) believe that the main factors to improve the competitiveness of the country's service trade include industrial scale, service openness, labor productivity and research investment. Second, the relationship between the development of service trade and national economic growth. On the basis of the intermediate goods trade model, Achenbach (2005) established the producer services trade model theory, believing that the knowledge-intensive producer services trade can increase the trade benefits. Cao Biao (2014) uses dynamic panel model and static panel model to analyze the producer services and consumer services trade impact on GDP growth, respectively, the results show that the producer service trade has a promoting effect on economic growth, consumer service trade has inhibitory effect on economic growth. Scholars at home and abroad have studied the relationship between service trade and environment mainly from three aspects: scale effect, technology effect and structure effect. 
Antweiler (2001) uses the model and takes SO2 as the pollution data, and studies show that the technological progress caused by service trade will reduce the pollution concentration by $1.25 \%$ to 1.5\%.He Jibe (2010) analyzed the influence of service trade on the emission intensity of China's waste water, carbon dioxide and so on, and concluded that the technical effect has the effect of pollution reduction to some extent. Fernandez (2008) studies have shown that under the framework of the North American free trade agreement, transport industry, service trade openness is higher, the more is beneficial to reduce the pollutant emissions by Mexico and Canada, improve air quality. From the perspective of environmental impact mode, Sun Arjun (2017) divides the service trade sector into direct impact (such as chimney service industry, accumulative service industry) and indirect impact (such as leveraged service industry) sectors. Lin Xi(2018), from the perspective of the added value of trade based on WWZ (2013) method to measure the added value of service trade level of 40 global economy, to study the regional service trade agreement to promote the export of service differentiation effect. Nagengast \& Stehrer (2016) used the world input-output database and input-output analysis technology to calculate the content of different value added in export products of various countries, and conducted transnational comparative analysis.

Based on the research of scholars, we through "diamond model" to build a harmonious evaluation index system of service trade subsystem according to production factors, demand situation, correlation and supporting industries. The environmental system is divided into two order parameters: emission intensity, energy and resource consumption, and then the coordination degree of the two is calculated. Finally, according to the results of the assessment, specific suggestions are proposed.

\section{Organization of the Text}

\subsection{Comparative Analysis on the Export of Service Trade.}

The difference between ecological environment and resource endowment affects the economic structure and trade pattern of countries. To compare three countries trade in services exports accounted for, this paper is divided into transportation service trade, tourism, construction, insurance, financial, communications, proprietary rights fee and royalty, and other business services. Than the annual average value of service trade exports in the three countries is calculated based on the annual data of various types of service trade exports. The specific situation is shown in Figure 1 below.

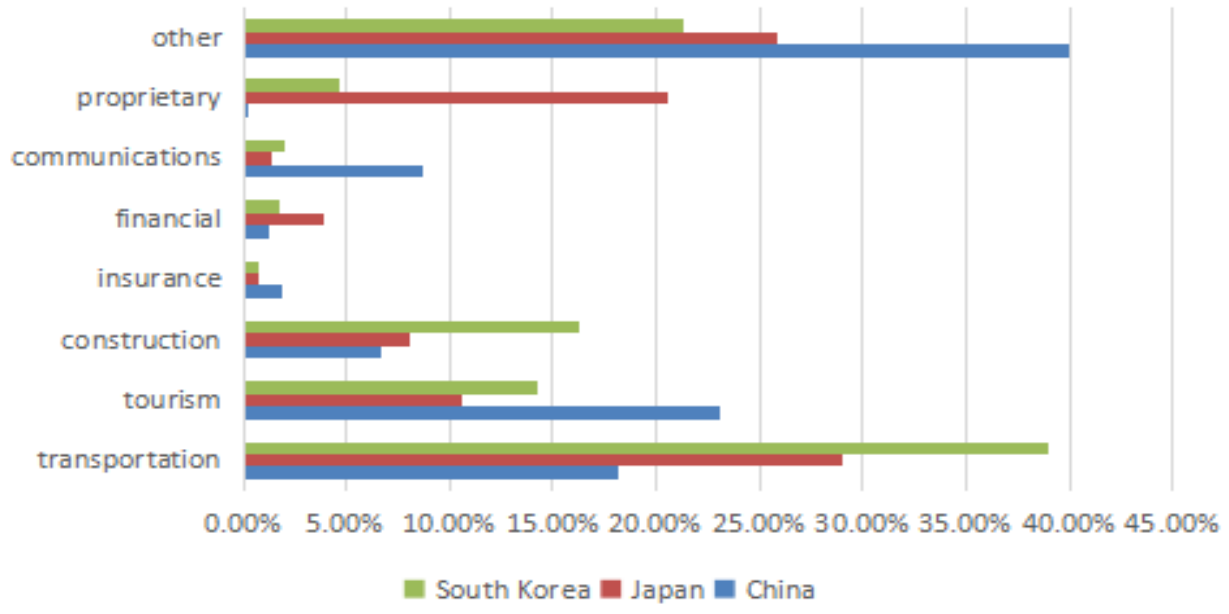

Fig 1. The average annual share of China, Japan and the South Korea in various service trade exports

Source: compiled from the OECD database and the China balance of payments table of the state administration of foreign exchange, 1982-2014 (BPMS).

China, Japan and South Korea to be discovered by figure 1 service trade export years an average of three countries is higher than in transportation and tourism, and the continuous development of transportation and tourism trade in services will produce a series of environmental problems, such as emissions of carbon dioxide, nitrogen oxides, etc. This provides a theoretical basis for constructing the indicators of the ecological environment system and is also the research basis of this paper. 
China's service trade is relatively backward and its overall competitiveness is weaker than that of developed countries such as Japan and South Korea. The total proportion of transportation and tourism in China's service trade exports is $41 \%$, which is relatively lower than that of Japan and Korea

\subsection{Methods and Data.}

Directly influence the coordination degree evaluation of the reason is that the determination of index weight method to determine the index weight are subjective values. The method and entropy value method, etc., to eliminate the influence of subjective factors, this paper choose the entropy value method. Entropy method is a mathematical method to determine the degree of dispersion of an index. The higher the degree of dispersion, the greater the influence of the index on the comprehensive evaluation. Basic calculation procedure are shown below.

$$
\begin{gathered}
S_{i j}=\left\{\begin{array}{l}
\frac{X_{i j}-\min \left(X_{i j}\right)}{\max \left(X_{i j}\right)-\min \left(X_{i j}\right)} \\
\frac{\max \left(X_{i j}\right)-X_{i j}}{\max \left(X_{i j}\right)-\min \left(X_{i j}\right)}
\end{array}\right. \\
U_{i}=\sum_{j=1}^{n} \omega_{i j} S_{i j}
\end{gathered}
$$

Formula (1) is to normalize the original data. Where, $\mathrm{D}$ is the coordination degree, $\mathrm{T}$ is the coordination index, and $\mathrm{C}$ is the coupling degree. A region in service trade import and export service trade development level, based on the theory of national competitive advantage service trade subsystem can be divided into production elements, demand conditions, related and supporting industries three order parameter. According to Cheng Hua (2011), the ecological environment subsystem is divided into two order parameters: emission intensity, energy and resource consumption. According to the entropy method, the weight of each index of service trade and ecological environment system was determined. Then, the coordination degree of the service trade and environment composite system of China, Japan and the South Korea is calculated using the system coordination degree model. Specific calculation results are shown in Table 1.

Table 1. Coupling degree and coordination degree of "service trade - ecological environment" system

\begin{tabular}{ccccccc}
\hline Year & $\begin{array}{c}\text { China } \\
\text { Coordination }\end{array}$ & $\begin{array}{c}\text { China } \\
\text { Coupling }\end{array}$ & $\begin{array}{c}\text { Japan } \\
\text { Coordination }\end{array}$ & $\begin{array}{c}\text { Japan } \\
\text { Coupling }\end{array}$ & $\begin{array}{c}\text { South Korea } \\
\text { Coordination }\end{array}$ & $\begin{array}{c}\text { South Korea } \\
\text { Coupling }\end{array}$ \\
\hline 2007 & 0.595 & 0.737 & 0.679 & 0.994 & 0.524 & 0.585 \\
2008 & 0.588 & 0.795 & 0.746 & 0.999 & 0.641 & 0.849 \\
2009 & 0.479 & 0.886 & 0.607 & 0.851 & 0.511 & 0.667 \\
2010 & 0.415 & 0.969 & 0.693 & 0.998 & 0.623 & 0.975 \\
2011 & 0.351 & 0.994 & 0.701 & 0.994 & 0.599 & 0.997 \\
2012 & 0.341 & 0.937 & 0.706 & 0.998 & 0.714 & 0.917 \\
2013 & 0.324 & 0.849 & 0.685 & 0.999 & 0.656 & 0.813 \\
2014 & 0.303 & 0.711 & 0.759 & 0.975 & 0.639 & 0.754 \\
2015 & 0.257 & 0.536 & 0.684 & 0.989 & 0.612 & 0.766 \\
2016 & 0.399 & 0.498 & 0.718 & 0.921 & 0.475 & 0.794 \\
\hline
\end{tabular}

According to the service trade and environment system in table 1 coupling coordination degree, coupling in China during 2007-2016 showed a trend of first of lowered later, up from 0.7367 in 2007 to 0.9937 in 2011, and decreased from 0.9937 in 2011 to 0.4981 in 2013. The coupling degree in Japan is above 0.9 except for 0.8506 in 2009, which is a high level coupling, with the maximum reaching 0.9999. The average coupling degree of South Korea fluctuates between [0.4750, 0.7142], which is lower than that of China and Japan, and the fluctuation range is large.

According to the results of the system coordination degree, the coordination degree of the "service trade -- environment" system of the three countries from 2007 to 2016 presents the regional characteristics that Japan is higher than Korea and Korea is higher than China. From 2007 to 2016, 
the average coupling coordination degree in China as a whole showed a downward trend. In 2016, it suddenly increased to 0.3985 . The coupling coordination degree of the whole Japan region around 0.7 horizontal line ups and downs, variable amplitude is small, a minimum of coordination degree value of 0.6, coordination degree in elementary coordination and intermediate fluctuations on coordination, shows that compared with the two countries, China and south Japan's service trade system and environment system coordination development best. Coupling coordination degree in South Korea area biggest, fluctuates up and down the overall rise in 2007-2012, 2012 peak of 0.7142, 2012 to 2016, began to decline year by year, minimum value of 0.475 in 2016, the coordination degree from barely coordination gradually rose to intermediate coordinate first, then decreased from intermediate coordinate to near disorders.

\section{Summary}

According to the above research, we find that the service trade scale and development level of the three countries are gradually increasing, and transportation and tourism service trade account for a significant proportion in all countries. From the results of regional system coordination, it is found that the two subsystems, service trade and environment, as a whole, do not develop together. The overall performance of China's service trade and ecosystem system coupling coordination is not good. Japan's coordination with South Korea is significantly higher than that of China's, and the degree of coordination is also shifting from one level to another trade in services and the environment have not yet formed a coordinated development mechanism, and its coordination has yet to be further improved. However, the scale of service trade, development level, waste water emission, carbon dioxide and solid waste non-emission intensity, energy and resource consumption intensity are all factors that influence the coordination degree. Therefore, in order to promote the coordinated development of East Asia service trade and environment composite system, and promote the sustainable development of service trade. This paper puts forward suggestions on optimizing production and service trade modes, accelerating the optimization and upgrading of service trade structure, and improving the quality of labor force in service industries.

\section{References}

[1]. Guerrier P, Feliciano V. Technology and International Competitiveness: The Interdependence between Manufacturing and Producer Services [Z].Structural Charge and Economic Dynamics 16489-02.2005.

[2]. Achenbach, F, and B. Hotelman. "Services Trade and FDI in Eastern Europe and Central Asia” [J], World Bank Working Paper.2005.

[3]. Antweiler, W, B, Copeland, and S. Taylor. Is Free Trade Good for the Environment? [J]. American Economic Review, 2001, (4).

[4]. Nagengast, A.J, and R. Sterner, 2016, “Accounting for the Differences between Gross and Value-added Trade Balances”, World Economy, 39(9):1276-1306.

[5]. Fernandez. NAFTA and member country strategies for maritime trade and marine invasive species. Journal of Environmental Management. Dec2008, Vol. 89 Issue 4, p308-321. 14p.

[6]. Cao Biao, Liao Living. Service trade structure and economic growth [J].World Economic research, 2014, (01):4-9.

[7]. He Jibe. Effects of international trade on the environment: industrial emissions of sulphur dioxide in Chinese provinces [J]. Economic Quarterly, 2010, (1): 415-446.

[8]. Lin $\mathrm{Xi}$. How do regional service trade agreements affect service trade flows?--from the perspective of value-added trade [J].Economic Research, 2018, 53(01):169-182. 
[9]. Wang, Z., S. J. Wei, and K. Zhu, 2013, “Quantifying International Production Sharing at the Bilateral and Sector Levels”, National Bureau of Economic Research No.w19677.

[10]. Cheng Hua, Liao Chonju. China regional environmental innovation performance evaluation and research [J]. China Environmental Science, 2011, 31 (3):522-528. 